\title{
BMJ Open Manitoba mothers and fetal alcohol spectrum disorders study (MBMomsFASD): protocol for a population-based cohort study using linked administrative data
}

\author{
Deepa Singal, ${ }^{1}$ Marni Brownell, ${ }^{1,2}$ Ana Hanlon-Dearman, ${ }^{3}$ Dan Chateau, ${ }^{4}$ \\ Sally Longstaffe, ${ }^{5}$ Leslie L Roos ${ }^{1,6}$
}

To cite: Singal $D$, Brownell M, HanlonDearman A, et al. Manitoba mothers and fetal alcohol spectrum disorders study (MBMomsFASD): protocol for a population-based cohort study using linked administrative data. BMJ Open 2016;6:e013330. doi:10.1136/bmjopen-2016013330

- Prepublication history for this paper is available online. To view these files please visit the journal online (http://dx.doi.org/10.1136/ bmjopen-2016-013330).

Received 4 July 2016 Revised 17 August 2016 Accepted 26 August 2016

\section{CrossMark}

For numbered affiliations see end of article.

Correspondence to Deepa Singal; DeepaKapoorSingal@gmail. com

\section{ABSTRACT}

Introduction: Fetal alcohol spectrum disorder (FASD) is a significant public health concern. To prevent FASD, factors that place women at risk for giving birth to children with FASD must be investigated; however, there are little data in this area. This paper describes the development of the Manitoba mothers and FASD study, a retrospective cohort of mothers whose children were diagnosed with FASD, generated to investigate: (1) risk factors associated with giving birth to children with FASD; (2) maternal physical and health outcomes, as well as the usage of health and social services.

Methods: The study population will be identified by linking children diagnosed with FASD from a provincially centralised FASD assessment clinic (from 31 March 1999 to 31 March 2012) to their birth mothers using de-identified administrative health data housed at the Manitoba Centre for Health Policy. Preliminary analysis has identified over 700 mothers, which is the largest sample size in this field to date. A comparison cohort of women with children who did not have an FASD diagnosis matched on the region of residence, date of birth of child with FASD and socioeconomic status will be generated to compare exposures and outcomes. Potential demographic, socioeconomic, family history, and physical and mental health risk factors will be investigated by linking a range of health and social databases, furthering insight into the root causes of drinking during pregnancy. The longitudinal data will allow us to document the usage patterns of healthcare and social services throughout significant periods in these women's lives to identify opportunities for prevention.

Ethics and dissemination: Ethical approval has been obtained by the University of Manitoba's Health Research Ethics Board and the Manitoba Health Information Privacy Committee. Dissemination of study results will include engagement of stakeholders and policymakers through presentations and reports for policymakers, in parallel with scientific papers.

\section{Strengths and limitations of this study}

Through the use of linked clinical and administrative data, the Manitoba Centre for Healthy Policy Data Repository allows the generation of the largest population-based sample of all women whose children were diagnosed with fetal alcohol spectrum disorder (FASD).

- The Manitoba FASD Centre offers a valid and reliable clinical diagnosis of FASD, and by linking these records to the birth mothers, we can be certain that women in this sample have given birth to children with FASD.

- Administrative data eliminate re-call bias and offer accurate information that can be isolated in critical periods of time throughout a study participant's lifespan.

- The study is subject to the limitations of administrative data and is reliant on the accuracy of data submitted by the organisations that deliver services.

- While we have taken great care in excluding all mothers with possible prenatal alcohol exposure and children with a diagnosis of FASD, we cannot be certain that there are no women in our comparison group who do not have un-reported prenatal alcohol use or children with undiagnosed FASD.

\section{BACKGROUND}

The prevention of fetal alcohol spectrum disorder (FASD) is a significant public health concern. In North America, over $10 \%$ of women report alcohol consumption during pregnancy. ${ }^{1}$ Prenatal alcohol use places infants at risk for FASD, an umbrella term comprising a range of effects associated with prenatal alcohol exposure. ${ }^{2}$ FASD has been recognised as the leading preventable cause of mental retardation in North America, highlighting FASD and prenatal alcohol consumption as 
substantial public health issues. ${ }^{2}$ Individuals with FASD experience myriad symptoms, including facial dysmorphology, growth restriction, central nervous system and neurodevelopmental abnormalities, as well as behavioural, emotional and social difficulties. ${ }^{23}$ Over the past decade, international FASD prevalence estimates have ranged from $2 \%$ to $5 \%$ in the general population and up to $23.3 \%$ in high-risk populations. ${ }^{5-14}$

FASD has been referred to as the world's only entirely preventable birth defect. Since the identification of fetal alcohol syndrome (FAS) in the 1970s, women who drink during pregnancy have been stigmatised and held responsible for causing this 'preventable' condition. ${ }^{15}$ The notion that this disorder can be prevented is rooted in the theory that the exposure can be easily eliminated. ${ }^{15}$ However, this response does not account for the many complex factors that influence women to engage in prenatal alcohol consumption, such as poverty, poor housing, trauma, physical and sexual abuse, mental disorders, lack of education and substance dependence. ${ }^{16} 17$ The use of alcohol during pregnancy cannot be separated from these issues in the lives of women, and from other potentially harmful behaviours such as poor health practices, poor nutrition and the use of other harmful substances. ${ }^{16} 17$ Only through identifying the demographic, social and economic factors that place women at risk for alcohol consumption during pregnancy can we obtain insight into the root causes of this behaviour and identify target points for prevention and support.

\section{What is known about women whose children are diagnosed with FASD?}

The WHO's global strategy to reduce the harmful use of alcohol highlights the importance of identification and prevention of the use of alcohol among pregnant women. ${ }^{18}$ Although a growing body of literature investigating prenatal alcohol use exists, there are limited data focusing on the birth mothers of children who are diagnosed with FASD.

A systematic literature review conducted in 2013 summarised studies that identified maternal factors associated with the development of FASD. ${ }^{19}$ The review identified 15 studies that were conducted throughout the world, including the USA, South Africa and New Zealand. ${ }^{9} 20-29$ The included studies summarised demographic factors, family and social factors, psychiatric and neuropsychological factors, and patterns of alcohol consumption, and identified the following maternal factors associated with the development of FASD: older age, lower educational level, lower socioeconomic status (SES), unemployment during pregnancy, rural residence, higher parity and gravidity, family relatives with alcohol abuse issues, mental disorders, psychological distress, physical and sexual abuse, use of tobacco and illicit drugs during pregnancy, and a more severe pattern of alcohol consumption in general and in pregnancy, including more binge drinking. ${ }^{19}$
What are the evidence gaps in the current literature?

While these studies have laid the groundwork for investigating factors associated with giving birth to children with FASD, they have several important limitations that may preclude them from informing FASD prevention strategies in North America:

1. Limited generalisability: first, there are no Canadian studies and few studies from the USA that were conducted at a population level. The majority of studies are from South Africa and Italy, and many focus on women who are from high-risk populations, such as indigenous populations. ${ }^{7} 232430$ Owing to differences in population demographics and cultural norms, caution should be taken when extrapolating these results to the general North American population.

2. Small sample sizes: previous studies have utilised small samples that range from 8 to 250 birth mothers. ${ }^{20} 22-2530$ These small sample sizes may be a function of the complexity of diagnosing children with FASD, particularly because alcohol consumption during pregnancy is underreported. ${ }^{4}{ }^{10}$ However, these sample sizes limit the generalisability of results, have limited power to detect significant differences among comparison groups and limit the ability to conduct powerful multivariate analyses.

3. Recall bias: the majority of studies in this area are also limited by recall bias from self-report survey and interview data. ${ }^{11} 2031-33$ There are many factors that affect the validity of self-report data in alcohol use during pregnancy, including severity of alcohol use disorder, issues of confidentiality, stigmatisation, fear of disclosure, fear of involvement of child welfare services, mental disorders and denial of alcohol use as a problem. ${ }^{25}{ }^{32}$ Moreover, the accuracy of the information provided by self-reports is questionable, especially during periods of high alcohol consumption, which affects memory and judgement. ${ }^{34}$

4. Limited data on diagnosed physical and mental health disorders: no previous studies have documented clinically diagnosed physical and mental health disorders in women who give birth to children with FASD using reliable and validated clinical data, highlighting an important gap in the literature. There is a strong association with mental health disorders and alcohol consumption $^{35-40}$ and investigating this relationship in women who give birth to children with FASD is extremely important for the advocacy of effective support and prevention strategies.

5. Limited data on service utilisation: a few studies have investigated prenatal care in this population through self-report data and have found that these women receive fewer prenatal visits compared to women in the general population, and generally begin prenatal care later in their pregnancies. ${ }^{23} 243041$ However, these results are limited by recall bias and do not report any other health or social services use. 
How can administrative health and social data help address evidence gaps?

The Manitoba mothers and FASD study (MBMomsFASD) is a data linkage project that will generate a retrospective cohort of all mothers who gave birth to children diagnosed with FASD in Manitoba, Canada. In partnership with the Manitoba FASD Centre (a provincially centralised FASD assessment and diagnostic clinic) and the Manitoba Centre for Healthy Policy (MCHP) (a population health research unit within the University of Manitoba, Canada), we will analyse explanatory variables associated with giving birth to children with FASD by analysing potential risk factors that are present before giving birth to a child with FASD (eg, SES, marital status, prenatal psychological distress, inadequate prenatal care), as well as maternal outcomes after the child with FASD is born (eg, postpartum psychological distress, suicide attempts and completion).

This study will make important contributions to the literature by filling existing gaps and addressing key methodological limitations identified in previous studies by using linked administrative health, social and education data housed at the MCHP. The MCHP Data Repository (herein referred to as the 'Repository') is one of the world's most comprehensive collections of populationbased administrative databases. These data are a powerful tool to investigate factors that promote the health of populations, as well as to understand the usage of healthcare services and social programmes of populations and specific groups. ${ }^{42}$ The Repository consists of populationwide administrative data from health and social service agencies, education institutions and Canadian Census, ${ }^{42-}$ ${ }^{44}$ which allow the investigation of outcomes from multiple domains in a cohort of individuals. ${ }^{42-44}$ This approach allows for an enhanced assessment of overall well-being and the impact of the multiple social determinants of health. This type of holistic investigation is particularly relevant to women who give birth to children with FASD. Women who drink during pregnancy often have histories that are rooted in abuse, poverty, other substance abuse and mental and/or physical illness. ${ }^{17} 4546$ Owing to the wealth of social and health data within the Repository, these data are an ideal source to investigate potential factors associated with prenatal alcohol consumption that results in the birth of a child with FASD. Administrative data are also ideal to investigate the usage of health and social systems among a population for any length of time or specified years. ${ }^{42-44} 4748$ We will document the usage of health and social systems among women whose children have been diagnosed with FASD to provide insight into how they navigate the health, social and education systems.

\section{Research questions}

1. What are the differences in: (a) demographic characteristics; (b) socioeconomic characteristics; (c) family characteristics; (d) psychiatric morbidity; (e) suicide behaviour; (f) physical morbidities, and (g) use of health and social services among women whose children have a clinical diagnosis of FASD compared to women whose children do not have a diagnosis of FASD?

2. What demographic, socioeconomic, family, mental and physical health characteristics are associated/predictive with giving birth to children with FASD compared to not giving birth to children with FASD?

\section{METHODS AND ANALYSIS}

Description of data sources

Records from the following data sources will be requested and linked together for analyses:

1. Manitoba FASD Centre. This data set includes information on all children assessed at the clinic from 31 March 1999 to 31 March 2012 and consists of children who have received a diagnosis of FASD, children who have been assessed but do not meet the criteria for FASD and those who have received a deferred status, meaning that they will be assessed at a later time (eg, when children are older, symptoms are more apparent). The clinic uses the Canadian diagnostic guidelines developed by Chudley et $a l^{2}{ }^{2}$ and the updated guidelines published by Cook et al. ${ }^{49}$ These guidelines include all alcohol-related disabilities that are included under the FASD definition: alcohol-related neurodevelopmental disorder (ARND), alcohol-related birth defects, FAS and partial FAS (pFAS). Diagnosis of FASD is conducted by a multidisciplinary team and FASD diagnosis typically includes screening and referral; physical examination and differential diagnosis; neurobehavioral assessment; and treatment and follow-up. ${ }^{2}$

2. MCHP Repository: The following databases will be utilised in this study:

A. The population registry: a registry maintained by the provincial department of health of all Manitobans eligible to receive health services since 1970 (updated semiannually) and includes demographic information and 6-digit residential postal code;

B. Canada census information: social data based on the Statistics Canada Population Census. These data were used to determine area-level income, with the Manitoba population divided into quintiles according to average area-level household income, composed of five income groupings with Q1 being the lowest and Q5 being the highest income quintile;

C. Employment and income assistance data from the Social Assistance Management Information Network that provide information on Manitoba residents who receive provincial employment and income assistance, a programme that provides financial assistance for meeting the basic needs of living.

D. Education data: education data maintained by the provincial department of education that provides information on enrolment, marks, and high 
school completion, and special funding. Special education funding is provided to children with severe to profound disabilities.

E. Babies first/families first screening programme data: data collected as part of a universal screening programme conducted by Healthy Child Manitoba. The screen is filled out by Public Health Nurses on all families with newborns in Manitoba and captures data on biological, social and demographic risk factors, including alcohol use during pregnancy.

F. Healthy baby prenatal benefit: data from the Healthy Baby programme, which provides an income supplement to help women meet nutritional needs during pregnancy and connects women to programmes and resources in their area;

G. InSight program data: data from an outreach program where mentors provide intensive support to substance-using women who are pregnant or have recently had a baby. This data set includes information on women who have prenatal alcohol use;

H. Justice system data: an incident tracking system maintained by the provincial department of justice. These data include information on incidents, charges and involvements (eg, witness, accused, victim) in the justice system in Manitoba;

I. Hospital discharge abstracts: consisting of all hospitalisations in Manitoba, including up to 16 ICD-9-CM diagnostic codes for discharges before 1 April 2004 and up to 25 ICD-10-CM diagnostic codes for discharges on or after 1 April 2004.

J. Medical/physician reimbursement claims: consisting of all ambulatory physician visits in Manitoba and include a single ICD-9 diagnostic code associated with each visit, coded to the third digit;

K. Pharmaceutical drug claims: containing all prescription drug claims from the Drug Program Information Network (DPIN, an electronic, online, point-of-sale prescription drug database that connects Manitoba Health and all pharmacies in Manitoba). Contains information on all prescription drugs dispensed in Manitoba;

L. Manitoba vital certificates mortality data: a longitudinal population-based registry maintained by Manitoba's Vital Statistical Agency that includes all Manitobans who have died since January 1970 to present and the cause of death;

M. Child and family services data: a data management system that supports case tracking and reporting of services provided to children and families as they are served through the Manitoba Child and Family services (CFS) System. This database includes information on children in care as well as information of families receiving protection and support services.

See table 1 for descriptions and years of data sets used for analysis.

\section{Data linkage}

De-identified health records are transferred to MCHP from Manitoba Health, Seniors and Active Living (MHSAL, government department that administers the universal health insurance programme for the province) and contain scrambled identifiers that allow for linkages across multiple databases and years of data. MHSAL acts as a third party for other non-health data providers to develop cross-walk files allowing individual-level linkages across different data sectors. Linkages are performed using de-identified personal health identification numbers, which are unique nine-digit numeric identifiers assigned by Manitoba Health to every person registered for health insurance in Manitoba.

The main sources of data for this work will be the MB FASD database and the databases identified above from the Repository. This linkage produces a powerful tool for studying children and families with FASD that combines the comprehensive health, social and education administrative data with detailed clinical information. For this study the first linkage will identify the study population through linking children identified as having a clinical diagnosis of FASD to their birth mothers. Children diagnosed with FASD through the MB FASD Centre will be linked to their mothers using the 'Hospital Newborn to Mother Linkage' which is a Registry file in the Repository. This file contains basic demographic and hospital data on newborns born in a hospital in Manitoba from 1984/1985 onward and their mothers. This file includes all live and stillbirths to Manitoba residents, and babies born in out of province hospitals to Manitoba residents, if reported to MHSAL. Babies not included are those: born out of hospital, born in Manitoba hospitals to out-of-province residents, those born out of province to Manitoba residents who are not reported to MHSAL. A baby's birth record is matched to the mother's obstetrical delivery record using PHINs. The next linkage involves linking the study population to several other Repository data sets (hospital, physician, drug and the social and educational databases specified above) through one-to-one links between PHINs and data records. For example a woman in the Repository identified as having given birth to a child diagnosed with FASD from the MB FASD data set will be linked to her individual hospital abstract records, physician claims records and prescription data records. No identifying information is used to merge these files as linkage is conducted through using encrypted PHINs in order to ensure the utmost privacy and confidentiality of the data of Manitobans.

Study Population: Two groups of women will be generated to address research questions.

Group 1 (Cases/Exposed): Mothers whose children have received a clinical diagnosis of FASD: Clinical data from the MB FASD Centre will be used to ascertain all children and youth (birth to 21 years of age) in Manitoba who have been diagnosed with FASD between 1999 and 2012. This database will be linked to administrative data from the 
Table 1 Description of data sets used for analysis and types of information retrieved

\begin{tabular}{|c|c|c|c|}
\hline Name of data set & Description of data set & $\begin{array}{l}\text { Years of data } \\
\text { used }\end{array}$ & Information retrieved \\
\hline Population Registry & $\begin{array}{l}\text { A registry maintained by Manitoba Health of } \\
\text { all Manitobans eligible to receive health } \\
\text { services since } 1970 \text { and includes } \\
\text { demographic information and 6-digit } \\
\text { residential postal code }\end{array}$ & $\begin{array}{l}1970 / 1971 \text { to } \\
\text { June } 2013\end{array}$ & $\begin{array}{l}\text { Demographic } \\
\text { information: region of } \\
\text { residence }\end{array}$ \\
\hline Canada Census Information & $\begin{array}{l}\text { Social data based on the Statistics Canada } \\
\text { Population Census. These data were used } \\
\text { to determine area-level income, with } \\
\text { Manitoba population divided into income } \\
\text { quintiles according to average area-level } \\
\text { household income, composed of five } \\
\text { possible income groupings with Q1 being } \\
\text { the lowest and Q5 being the highest income } \\
\text { quintile }\end{array}$ & $\begin{array}{l}\text { 1996, 2001, 2006, } \\
2013\end{array}$ & SES information \\
\hline $\begin{array}{l}\text { Employment and Income } \\
\text { Assistance Data }\end{array}$ & $\begin{array}{l}\text { Data maintained by Manitoba Jobs and the } \\
\text { Economy that provide information on } \\
\text { Manitoba residences who receive provincial } \\
\text { employment and income assistance }\end{array}$ & $\begin{array}{l}1995 / 1996 \text { to } \\
2012 / 2013\end{array}$ & SES information \\
\hline $\begin{array}{l}\text { Education data: Enrolment, } \\
\text { Marks and Assessments }\end{array}$ & $\begin{array}{l}\text { Education data maintained by Manitoba } \\
\text { Education and Advanced Learning that } \\
\text { provides information on enrolment, marks } \\
\text { and high school completion, and special } \\
\text { funding. Special education funding is } \\
\text { provided to children with severe to profound } \\
\text { disabilities }\end{array}$ & $\begin{array}{l}1995 / 1996 \text { to } \\
2012 / 2013\end{array}$ & $\begin{array}{l}\text { High school completion, } \\
\text { level of special education } \\
\text { funding }\end{array}$ \\
\hline $\begin{array}{l}\text { Baby First/Families First } \\
\text { Screening Program data }\end{array}$ & $\begin{array}{l}\text { Data collected as part of a universal } \\
\text { screening programme conducted by Healthy } \\
\text { Child Manitoba. The screen is filled out by } \\
\text { Public Health Nurses on all families with } \\
\text { newborns in Manitoba and captures data on } \\
\text { biological, social and demographic risk } \\
\text { factors, including alcohol use during } \\
\text { pregnancy }\end{array}$ & $\begin{array}{l}2003 \text { to } \\
2013=\text { Families } \\
\text { First } \\
2000 \text { to } \\
2002=\text { Baby First }\end{array}$ & $\begin{array}{l}\text { Alcohol and drug use } \\
\text { during pregnancy } \\
\text { Maternal education } \\
\text { Social isolation }\end{array}$ \\
\hline $\begin{array}{l}\text { Healthy Baby Prenatal Benefit } \\
\text { and Healthy Baby Community } \\
\text { Support Program }\end{array}$ & $\begin{array}{l}\text { Data from the Healthy Baby programs } \\
\text { (administered by Healthy Child Manitoba), } \\
\text { which provide financial benefits to help } \\
\text { women meet nutritional needs during } \\
\text { pregnancy and connects women to } \\
\text { programs and resources in their area }\end{array}$ & $\begin{array}{l}2001 \text { to } 2011 / \\
2012\end{array}$ & $\begin{array}{l}\text { Demographic and SES } \\
\text { information } \\
\text { Program participation }\end{array}$ \\
\hline InSight Program data & $\begin{array}{l}\text { Includes data from an outreach program } \\
\text { where mentors provide intensive support to } \\
\text { women who are pregnant or have recently } \\
\text { had a baby and use substances. This data } \\
\text { set includes information on women who } \\
\text { have prenatal alcohol use }\end{array}$ & $\begin{array}{l}1999 \text { to } 2012 / \\
2013\end{array}$ & $\begin{array}{l}\text { Alcohol and substance } \\
\text { use during pregnancy }\end{array}$ \\
\hline Hospital Abstracts & $\begin{array}{l}\text { Health data maintained by Manitoba Health } \\
\text { consisting of all hospitalisations in Manitoba, } \\
\text { including up to } 16 \text { ICD-9-CM diagnostic } \\
\text { codes for discharges before } 1 \text { April } 2004 \\
\text { and up to } 25 \text { ICD-10-CM diagnostic codes } \\
\text { for discharges on or after } 1 \text { April } 2004\end{array}$ & $\begin{array}{l}1984 \text { to } 2012 / \\
2013\end{array}$ & $\begin{array}{l}\text { Physical and mental } \\
\text { health diagnoses } \\
\text { Antenatal hospitalisations } \\
\text { Suicide attempts }\end{array}$ \\
\hline $\begin{array}{l}\text { Medical/Physician } \\
\text { reimbursement claims }\end{array}$ & $\begin{array}{l}\text { Health data maintained by Manitoba Health } \\
\text { consisting of all ambulatory physician visits } \\
\text { in Manitoba and include a single ICD-9 } \\
\text { diagnostic code associated with each visit, } \\
\text { coded to the third digit }\end{array}$ & $\begin{array}{l}1984 \text { to } 2012 / \\
2013\end{array}$ & $\begin{array}{l}\text { Physical and mental } \\
\text { health diagnoses } \\
\text { Physician visits } \\
\text { Prenatal care }\end{array}$ \\
\hline
\end{tabular}


Table 1 Continued

\begin{tabular}{|c|c|c|c|}
\hline Name of data set & Description of data set & $\begin{array}{l}\text { Years of data } \\
\text { used }\end{array}$ & Information retrieved \\
\hline $\begin{array}{l}\text { Prescription claims data: Drug } \\
\text { Program Information Network }\end{array}$ & $\begin{array}{l}\text { Data maintained by Manitoba Health } \\
\text { containing all prescription drug claims from } \\
\text { the DPIN (an electronic, online, point-of-sale } \\
\text { prescription drug database that connects } \\
\text { Manitoba Health and all pharmacies in } \\
\text { Manitoba). Contains information on all } \\
\text { prescription drugs dispensed in Manitoba }\end{array}$ & $\begin{array}{l}1995 / 1996 \text { to } \\
2012 / 2013\end{array}$ & $\begin{array}{l}\text { Physical and mental } \\
\text { health diagnoses }\end{array}$ \\
\hline Manitoba FASD Centre data & $\begin{array}{l}\text { Includes clinical assessments and } \\
\text { diagnoses received under the FASD } \\
\text { umbrella for all children referred to the MB } \\
\text { FASD Centre }\end{array}$ & $\begin{array}{l}1999 \text { to } 2012 / \\
2013\end{array}$ & $\begin{array}{l}\text { FASD diagnosis } \\
\text { Children diagnosed with } \\
\text { FASD }\end{array}$ \\
\hline Vital statistics data & $\begin{array}{l}\text { A longitudinal population-based registry } \\
\text { maintained by Manitoba's Vital Statistics } \\
\text { Agency that includes all Manitobans who } \\
\text { have died since January } 1970 \text { to present } \\
\text { and the cause of death }\end{array}$ & $\begin{array}{l}1970 \text { to } 2012 / \\
2013\end{array}$ & $\begin{array}{l}\text { Cause of premature } \\
\text { death } \\
\text { Suicide completion }\end{array}$ \\
\hline $\begin{array}{l}\text { Justice System: The } \\
\text { Prosecutions Information } \\
\text { Management System }\end{array}$ & $\begin{array}{l}\text { An incident tracking system maintained by } \\
\text { Manitoba Justice. These data include } \\
\text { information on incidents, charges and } \\
\text { involvements (eg, witness, accused, victim) } \\
\text { in the justice system in Manitoba }\end{array}$ & $\begin{array}{l}2002 \text { to } 2011 / \\
2012\end{array}$ & $\begin{array}{l}\text { Justice system } \\
\text { involvement }\end{array}$ \\
\hline $\begin{array}{l}\text { Child and Family Services } \\
\text { Information System }\end{array}$ & $\begin{array}{l}\text { A data management system that supports } \\
\text { case tracking and reporting of services } \\
\text { provided to children and families as they } \\
\text { pass through the CFS system. This } \\
\text { database includes information on children in } \\
\text { care as well as information of families } \\
\text { receiving protective and support services }\end{array}$ & $\begin{array}{l}1992 / 1993 \text { to } \\
2012 / 2013\end{array}$ & Involvement with CFS \\
\hline
\end{tabular}

CFS, Manitoba Child and Family services; DPIN, Drug Program Information Network; FASD, Fetal alcohol spectrum disorder; SES, socioeconomic status.

MCHP Repository to identify these children's birth mothers. Only mothers who can be linked to their children (who had a baby-mother linkage), who have postal code information and who were Manitoba residents registered to receive healthcare in the province and covered from their birth until March 2012 will be included. If a mother has multiple children diagnosed with FASD, we will use the first child diagnosed with FASD as the index child.

Group 2 (Comparison group/unexposed): mothers whose children have not received a clinical diagnosis of FASD: Women whose children have never received an FASD diagnosis from the MB FASD Centre, with no known record of prenatal alcohol use in the databases available, and whose children have no evidence of FASD from the Repository will be matched to the exposed group of women on the date of month of birth of the index child, SES and region of residence. Matching will be performed without replacement, at a ratio of three controls for each case. To decrease the likelihood that the comparison women have children with undiagnosed FASD, the following exclusion criteria will be used: (1) women with any children assessed at the Manitoba FASD Centre; (2) women with children who had a diagnosis of FASD as recorded in hospital or physician claims data using the following ICD codes: a hospital visit with ICD
9CM code 760.71, ICD 10CCA code of 86.0 or a physician visit with any ICD 9 code 760; (3) women who had children who had prescriptions for psychostimulants or risperidone; (4) women with children diagnosed with ADHD (due to high comorbidity with a diagnosis of FASD and ADHD $;^{50} 51$ (5) women involved in the InSight Mentoring programme (a programme that provides support for women with alcohol and substance abuse issues); (6) women with a history of substance abuse disorder (including alcohol) during pregnancy as indicated by the physician and hospital claims; (7) women whose newborn risk screen indicates they had used alcohol during pregnancy; and (8) women whose children received special education funding indicating they had severe to profound disabilities.

\section{Study design}

Two study designs will be used based on the two different research questions being addressed.

\section{Research question 1}

A retrospective matched cohort study design will be used to investigate differences in rates of psychiatric morbidity, suicide attempts and completion, physical health disorders and usage of health and social services (outcome 
variables) (see figure 1) between our exposed group (group 1) and our unexposed group (group 2) before and after the birth of the index child.

\section{Research question 2}

A retrospective matched case-control design will be used to investigate potential risk factors (exposure variables) associated with giving birth to a child with FASD (outcome) (see figure 2). Our case group (group 3) will be compared to our comparison group (group 4) to investigate whether they had the following risk factors before the birth of the child and whether these factors were associated with giving birth to children with FASD: demographic and socioeconomic factors, family history,

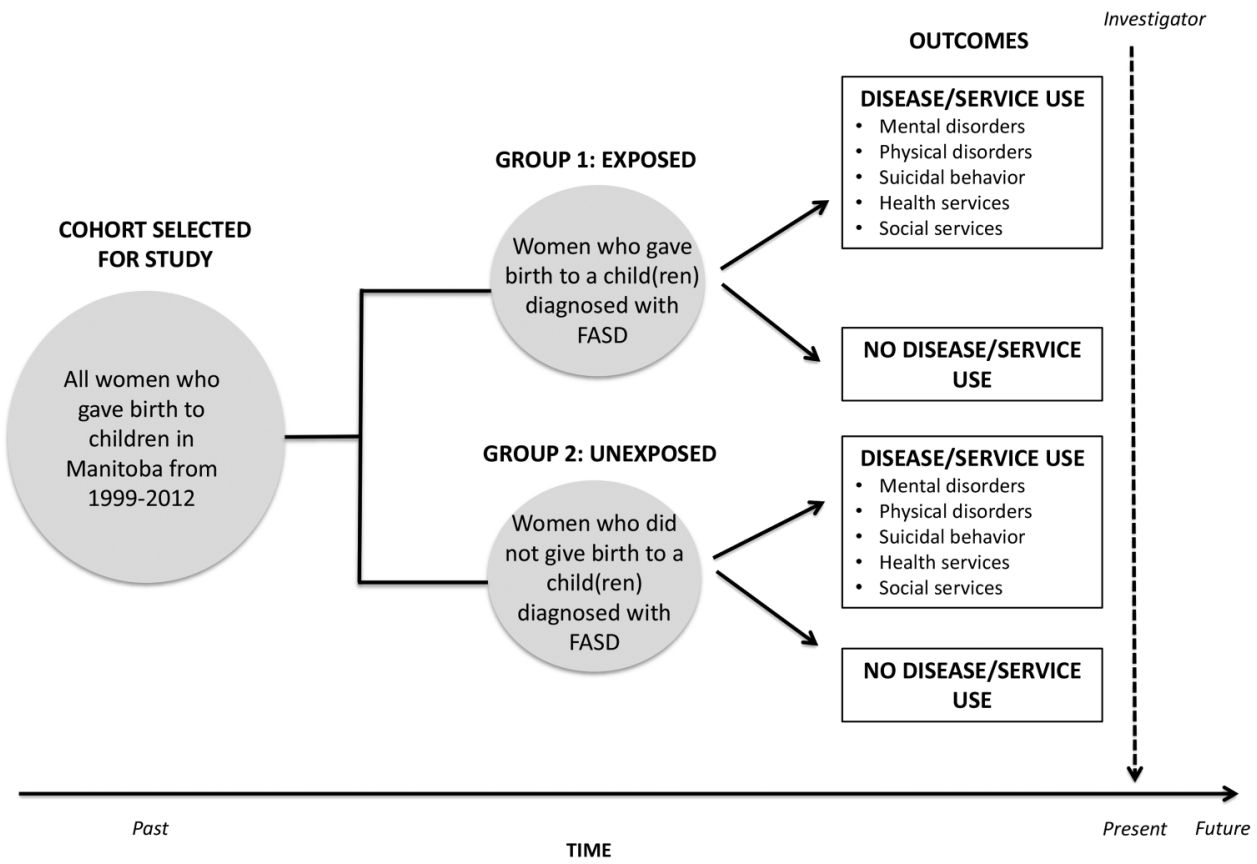

Figure 1 A retrospective matched cohort study design to investigate differences in rates of psychiatric morbidity, suicide attempts and completion, physical health disorders and health and social services utilisation between the exposed unexposed group before and after the birth of the index child.

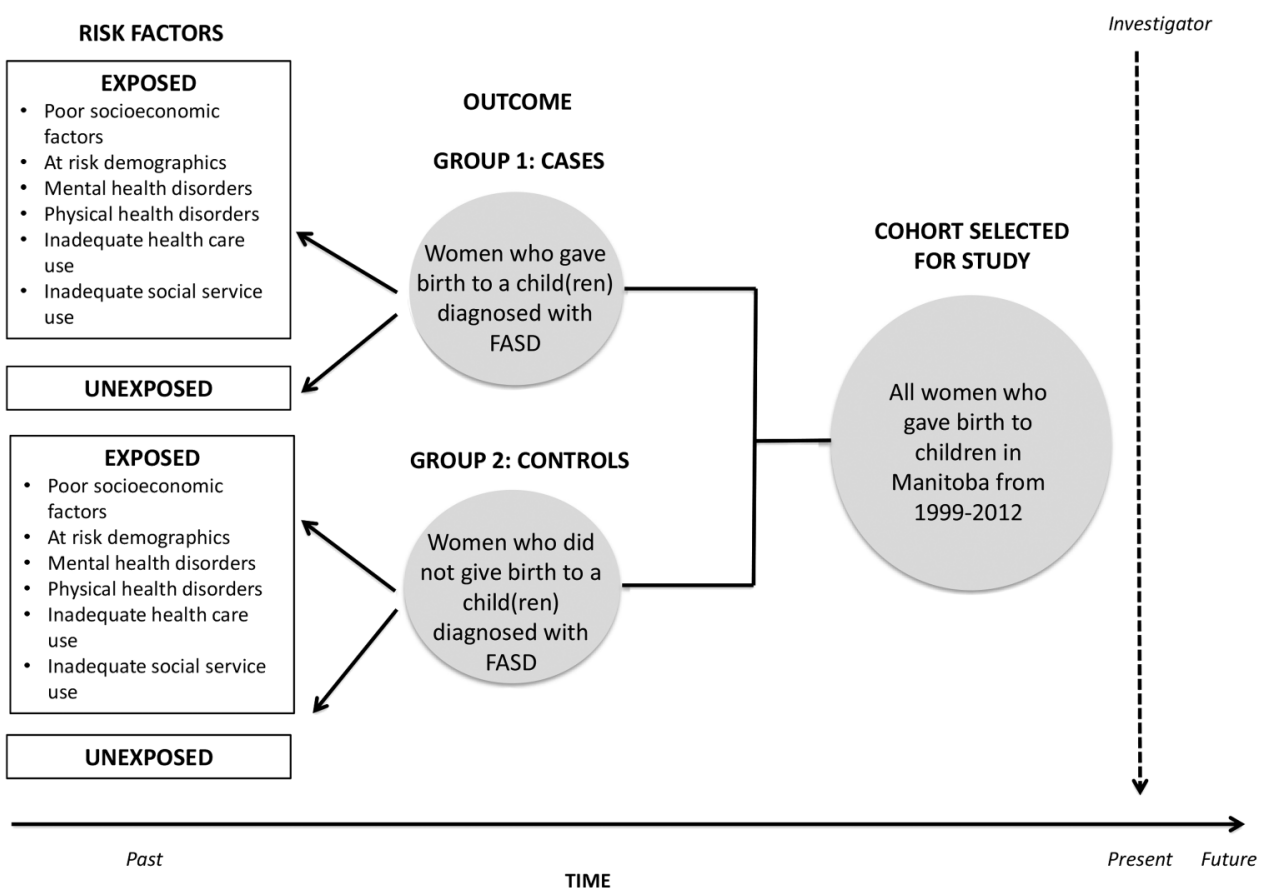

Figure 2 A retrospective matched case-control design to investigate potential risk factors associated with giving birth to a child with fetal alcohol spectrum disorder. 
mental disorder diagnoses, physical health diagnosis, use of healthcare and social services.

\section{Analysis plan: research question 1 \\ Outcomes}

To investigate health outcomes and use of services among our exposed and unexposed groups, the following outcomes will be investigated:

A. Psychiatric morbidity: diagnosis of substance abuse disorder, personality disorder, mood and anxiety disorder, and schizophrenia 3 years prior to the birth of the index child. Prenatal psychological distress ( 8 months prior to the birth of the index child) and postnatal psychological distress (from birth to 12 months prior to the birth of the index child) (see table 2 for definitions)

B. Suicidal behaviour: suicide attempts (3 years before the birth of the index child, during pregnancy, during the postpartum period, until the end of the study period) and completion (from birth to the end of the study period) (table 3).

C. Physical health disorders: diabetes, hypertension, ischaemic heart disease, total respiratory morbidity (3 years prior to the birth of the index child) (see table 4 for definitions).

D. Use of healthcare service: average number of physician/ambulatory visits 1 year before the pregnancy with the index child, average number of physician/ ambulatory visits during the pregnancy with the index child, average number of all hospitalisations 3 years before the birth of the child, average number of antenatal hospitalisations 3 years before the birth of the index child, late initiation of prenatal care, no prenatal care, low number of prenatal visits, inadequate prenatal care (see table 5)

E. Use of social services: receipt of healthy baby prenatal benefit (1 year prior to the birth of the child), participation in healthy baby support program ( 1 year prior to the birth of the child), participation in InSight Mentoring programme (1 year prior to the birth of the child), record of a Family First/Baby First Screen (after the birth of the index child) (see table 6).

Statistical analysis: Univariate statistics, including proportions and means, will be calculated for all outcome variables (ie, events). Adjusted relative rates for all outcomes will be calculated using generalised estimating equations with a Poisson distribution. A negative binomial distribution will be used if data are overdispersed. Both models are suitable for non-normally distributed data such as counts. All analyses will test for differences between study groups and will adjust for the following covariates: receipt of income assistance, SES (low, middle, high), age of mother at birth of child (18 or under, 19 to 24,25 to 34,35 and over).

To model the rates of events for our two groups, we will create a summary data set for the total number of events (eg, total number of mothers with mood and anxiety disorder) for unique strata and the total number of per-person years at risk for the strata. We will include the log of the total number of person-years as an offset in the model to produce an analysis of rates of events, rather than simple counts, and to generate estimates of adjusted RRs of events. This procedure will ensure that any variation in follow-up times for women in the study groups will be accounted for.

\section{Analysis plan: research question 2}

To investigate potential risk factors associated with giving birth to a child with FASD, the following exposure variables will be investigated 5 years prior to the birth of the index child for our case and comparison group:

A. Demographic and socioeconomic factors: maternal age at birth of index child, maternal age at first birth, history of teen pregnancy, region of residence, mean household income, SES, receipt of income assistance, high school completion, involvement with the justice system (see table 7 for definitions);

B. Family history: marital status, gravidity, parity, birth order of the index child (first, middle, last), involvement with CFS, type of FASD diagnosis of child (see table 8 for definitions);

C. Diagnosis of a mental disorder: substance abuse disorder, personality disorder, mood and anxiety disorder, schizophrenia, prenatal psychological distress, suicide attempts (table 2);

D. Diagnosis of a physical health disorder: diabetes, hypertension, ischaemic heart disease, total respiratory morbidity (table 4 );

E. Quality of prenatal care: late initiation of prenatal care, no prenatal care, low number of prenatal visits, inadequate prenatal care (table 5).

Statistical analysis: research question 2: univariate statistics will be used to describe all potential risk factors for cases and comparison women. Bivariate associations between each independent variable and outcome (having a child with FASD) will be conducted as a preliminary investigation of the relationship between the outcome and risk factor. Associations between groups will be tested using t-tests for continuous variables and Pearson's $\chi^{2}$ tests for categorical variables. Variables with a $p$ value of $\leq 0.2$ in the bivariate analysis will be included in a multivariate regression analysis using conditional logistic regression, which is appropriate for studies using a matched casecontrol design, and accounts for observations that are correlated. Goodness-of-fit tests will be run to test the fit of the model and diagnostics will be run to assess collinearity between independent variables.

\section{DISCUSSION}

The MBMomsFASD is the largest, most comprehensive, in-depth investigation into the characteristics, health and mental health, and use of services among women whose children have been diagnosed with FASD. This study offers numerous methodological advantages over 
Table 2 Definitions of mental disorders exposure/outcome variables

\begin{tabular}{|c|c|c|c|}
\hline Variable & Time frame & Database & Operation definition/ICD codes \\
\hline $\begin{array}{l}\text { Diagnosis of a } \\
\text { psychiatric disorder }\end{array}$ & $\begin{array}{l}3 \text { years prior to the birth of } \\
\text { the index child }\end{array}$ & $\begin{array}{l}\text { Physician } \\
\text { claims } \\
\text { Hospital } \\
\text { abstracts } \\
\text { Prescription } \\
\text { claims }\end{array}$ & $\begin{array}{l}\text { A woman was considered to have a psychiatric disorder if she had one of the following (see } \\
\text { specific definitions below): substance abuse disorder, personality disorder, mood and anxiety } \\
\text { disorder, schizophrenia or prenatal psychological distress }\end{array}$ \\
\hline $\begin{array}{l}\text { Substance abuse } \\
\text { disorder }\end{array}$ & $\begin{array}{l}3 \text { years prior to the birth of } \\
\text { the index child }\end{array}$ & $\begin{array}{l}\text { Physician } \\
\text { claims } \\
\text { Hospital } \\
\text { Abstracts } \\
\text { Prescription } \\
\text { claims }\end{array}$ & $\begin{array}{l}\text { A woman was considered to have a substance use disorder if } 5 \text { years prior to the birth of the } \\
\text { child she had: } \\
\text { 1. One or more hospitalisations with a diagnosis for alcohol or drug psychoses, alcohol or drug } \\
\text { dependence, or non-dependent abuse of drugs (ICD-9-CM codes 291, 292, 303, 304, 305, } \\
\text { ICD-10-CM codes: F10-F19 and F55) OR } \\
\text { 2. One or more physician visits with a diagnosis for alcohol or drug psychoses, alcohol or drug } \\
\text { dependence, or non-dependent abuse of drugs using the same ICD-9-CM codes listed } \\
\text { above }\end{array}$ \\
\hline Personality disorder & $\begin{array}{l}3 \text { years prior to the birth of } \\
\text { the index child }\end{array}$ & $\begin{array}{l}\text { Physician } \\
\text { claims } \\
\text { Hospital } \\
\text { abstracts } \\
\text { Prescription } \\
\text { claims }\end{array}$ & $\begin{array}{l}\text { A women was considered to have a personality disorders if in the } 5 \text { years prior to giving birth to } \\
\text { the child she had the following: } \\
\text { 1. One or more hospitalisations with a diagnosis of personality disorder (ICD-9-CM code } 301 \\
\text { or ICD-10- CA codes F34.0, F60, F61, F62, F68.1, F68.8, or F69) OR } \\
\text { 2. One or more physician visits with a diagnosis of personality disorder: (ICD-9-CM code 301) }\end{array}$ \\
\hline $\begin{array}{l}\text { Mood and anxiety } \\
\text { disorder }\end{array}$ & $\begin{array}{l}3 \text { years prior to the birth of } \\
\text { the index child }\end{array}$ & $\begin{array}{l}\text { Physician } \\
\text { claims } \\
\text { Hospital } \\
\text { abstracts } \\
\text { Prescription } \\
\text { claims }\end{array}$ & $\begin{array}{l}\text { A women was considered to have mood or anxiety disorder if in the } 5 \text { years prior to giving birth } \\
\text { to the child she had the following: } \\
\text { 1. One or more hospitalisations with a diagnosis for depressive disorder, affective psychoses, } \\
\text { neurotic depression or adjustment reaction: ICD-9-CM codes } 296.1-296.8,300.4,309 \text { or } \\
\text { 311; ICD-10-CA codes F31, F32, F33, F34.1, F38.0, F38.1, F41.2, F43.1, F43.2, F43.8, } \\
\text { F53.0, F93.0 or with a diagnosis for an anxiety state, phobic disorders or obsessive- } \\
\text { compulsive disorders: ICD-9-CM codes 300.0, 300.2, 300.3, 300.7; ICD-10-CA codes F40, } \\
\text { F41.0, F41.1, F41.3, F41.8, F41.9, F42, F45.2; OR } \\
\text { 2. F48, F68.0, or F99 AND one or more prescriptions for an antidepressant or mood stabiliser, } \\
\text { including medications with the ATC codes N05AN01, N05BA, NO6A; OR } \\
\text { 3. One or more physician visits with a diagnosis for depressive disorder or affective psychoses: } \\
\text { ICD-9-CM codes 296, 311; OR } \\
\text { 4. One or more physician visits with a diagnosis for anxiety disorders: ICD-9-CM code } 300 \\
\text { AND one or more prescriptions for an antidepressant or mood stabiliser, including } \\
\text { medications with the ATC codes N05AN01, NO5BA, N06A; OR } \\
\text { 5. Three or more physician visits with a diagnosis for anxiety disorders or adjustment reaction: } \\
\text { ICD-9-CM code 300, } 309\end{array}$ \\
\hline Schizophrenia & $\begin{array}{l}3 \text { years prior to the birth of } \\
\text { the index child }\end{array}$ & $\begin{array}{l}\text { Physician } \\
\text { claims } \\
\text { Hospital } \\
\text { abstracts } \\
\text { Prescription } \\
\text { claims } \\
\end{array}$ & $\begin{array}{l}\text { A women was considered to have schizophrenia if in the } 5 \text { years prior to giving birth to the child } \\
\text { had the following: } \\
\text { 1. One or more hospitalisations or physician visits with a diagnosis of schizophrenia: ICD-9-CM } \\
\text { code } 295 \text { or ICD-10-CA codes F20, F21, F23.2, F25; OR } \\
\text { 2. One or more physician visits with a diagnosis of schizophrenia: ICD-9-CM code } 295 \text {. }\end{array}$ \\
\hline
\end{tabular}




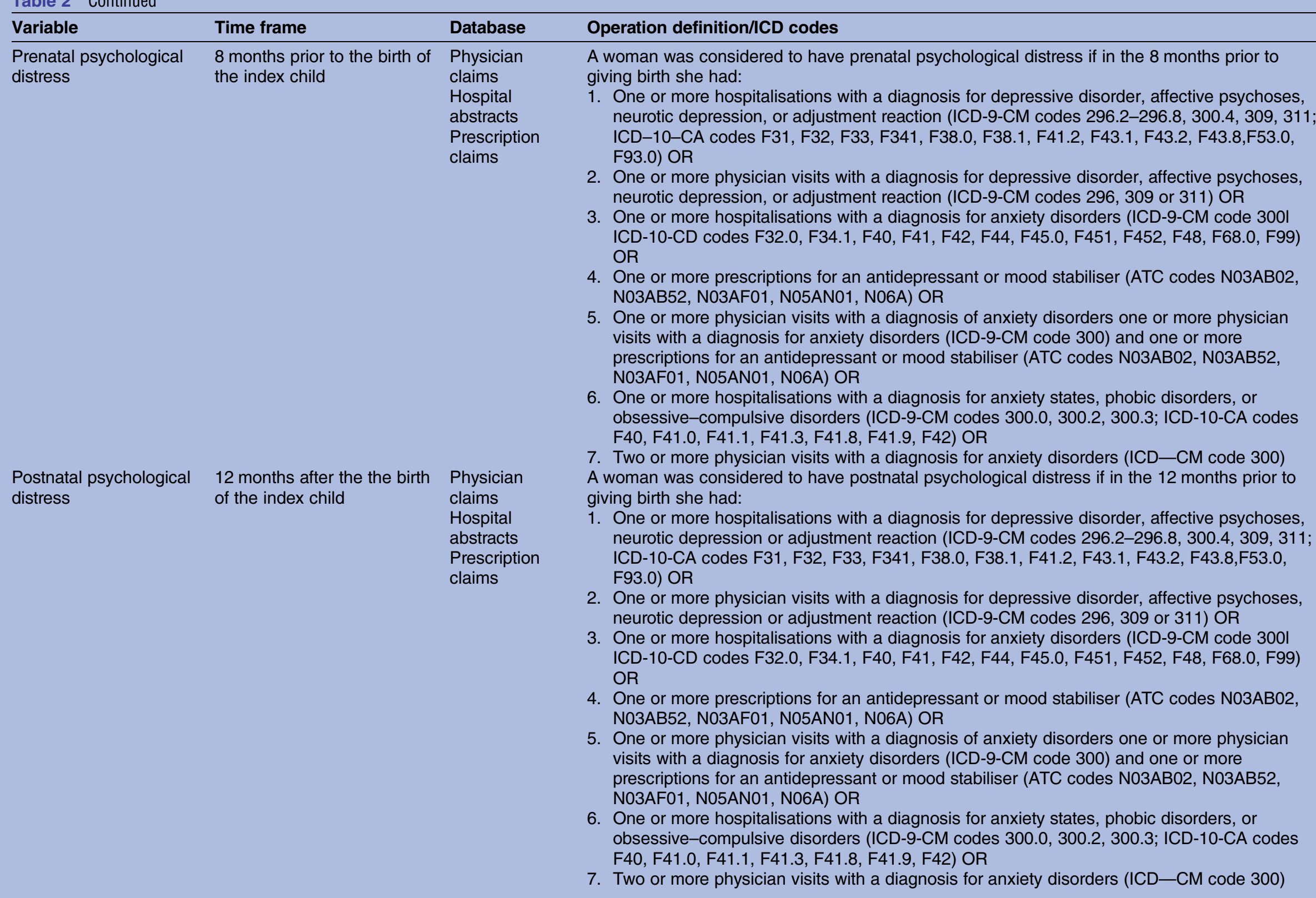


Table 3 Definitions of suicide behaviour exposure/outcome variables

\begin{tabular}{|c|c|}
\hline Variable & Time frame \\
\hline $\begin{array}{l}\text { Suicide } \\
\text { attempts }\end{array}$ & $\begin{array}{l}5 \text { years prior to the birth of the } \\
\text { index child } \\
\text { During pregnancy } \\
\text { During the postpartum period } \\
\text { From } 1 \text { year after the birth of } \\
\text { the child until the end of the } \\
\text { study period }\end{array}$ \\
\hline
\end{tabular}

Database

Physician claims Hospital abstracts the child until the end of the study period

Suicide completion
From birth until the end of the study period
Vital Statistics Mortality Data

\section{Operation definition/ICD codes}

A women was considered to have attempted suicide if 5 years prior to the birth of the child she had:

1. One hospitalisation with a diagnosis for suicide and self-inflicted injury: ICD-9-CM codes E950-E959, ICD-10-CA codes X60-X84; OR

2. One hospitalisation with a diagnosis code for accidental poisoning:

3. ICD-9-CM codes 965, 967, 969, 977.9, 986, E850-E854, E858, E862,

4. E868; ICD-10-CA codes T39, T40,T42.3, T42.4, $\mathrm{T} 42.7, \mathrm{~T} 43, \mathrm{~T} 50.9$,

5. T58, X40-X42, X44, X46, X47, Y10-Y12, Y16, Y17, only if there is a

6. Physician visit with a diagnosis code for accidental poisoning and $a$

7. Psychiatric tariff code either during the hospital stay or within 30 days

8. Postdischarge. Psychiatric tariff codes are as follows:

9. From the psychiatric schedule:

- 8444 Psychotherapy - group of two to four patients

- 8446 Psychotherapy-group of five or more patients

- 8472 Child and Youth Management Conference

- 8475 Psychiatry—Patient Care Family Conference

- 8476 Psychiatric Social Interview

- 8503 Complete history and psychiatric examinationadult

- 8504 Complete history and psychiatric examinationchild

- 8553 Psychiatry Consultation-adult

- 8554 Psychiatry Consultation-child

- 8581 Psychotherapy-individual

- 8584 Psychiatric care-individual

- 8588 Electroshock therapy

- 8596 Consultation-Unassigned patient-child

From the general schedule:

- 8580 Psychotherapy-individual

- 8587 Electroshock therapy

- 8589 Psychotherapy-group

A women was considered to have completed suicide if the following ICD codes were used in the 'cause of death' field in the Vital Statistics Mortality Data (our definition including accidental poisonings):

1. Accidental poisoning: ICD-9 codes E850-E854, E858, E862, E868;

2. ICD-10 codes $\mathrm{X} 40-\mathrm{X} 42, \mathrm{X} 46, \mathrm{X} 47$ OR poisoning with undetermined intent: ICD-10 codes Y10-Y12, Y16, Y17 OR

3. Self-inflicted poisoning: ICD-9 codes E950-E952, ICD-10 codes X60-X69 OR

4. Self-inflicted injury by hanging, strangulation and suffocation: ICD-9 code E953, ICD-10 code X70 OR

5. Self-inflicted injury by drowning: ICD-9 code E954, ICD-10 code X71 OR

6. Self-inflicted injury by firearms and explosives: ICD-9 code E955, ICD-10 codes X72-X75 OR 
Table 3 Continued

\begin{tabular}{|c|c|c|c|}
\hline Variable & Time frame & Database & Operation definition/ICD codes \\
\hline & & & $\begin{array}{l}\text { 7. Self-inflicted injury by smoke, fire, flames, steam, } \\
\text { hot vapours and hot objects: ICD-9 codes E958.1, } \\
\text { E958.2; ICD-10 codes X76, X77 OR } \\
\text { 8. Self-inflicted injury by cutting and piecing } \\
\text { instruments: ICD-9 code E956; ICD-10 codes X78, } \\
\text { X79 OR } \\
\text { 9. Self-inflicted injury by jumping from high places: } \\
\text { ICD-9 code E957, ICD-10 code X80 OR } \\
\text { 10. Self-inflicted injury by jumping or lying before a } \\
\text { moving object: ICD-9 code E958.0, ICD-10 code } \\
\text { X81 OR } \\
\text { 11. Self-inflicted injury by crashing of motor vehicle: } \\
\text { ICD-9 code E958.5, ICD-10-CA code X82 OR } \\
\text { 12. Self-inflicted injury by other and unspecified means: } \\
\text { ICD-9 codes E958.3, E958.4, E958.6-E958.9; } \\
\text { ICD-10 codes X83, X84 ORlate effects of } \\
\text { self-inflicted injury: ICD-9 code E959 }\end{array}$ \\
\hline
\end{tabular}

Table 4 Definitions of physical health disorders exposure/outcome variables

\begin{tabular}{|c|c|c|c|}
\hline Variable & Time frame & Database & Operation definition/ICD codes \\
\hline Hypertension & $\begin{array}{l}5 \text { years prior to the } \\
\text { birth of the index child }\end{array}$ & $\begin{array}{l}\text { Physician } \\
\text { claims } \\
\text { Hospital } \\
\text { abstracts } \\
\text { Prescription } \\
\text { claims }\end{array}$ & $\begin{array}{l}\text { A woman was considered to have a history of hypertension if } \\
5 \text { years prior to the birth of the child she had: } \\
\text { 10. At least one physician visit or one hospitalisation with an } \\
\text { ICD-9-CM code of } 401-405 \text { (ICD-10-CA codes I10-I13, I15), } \\
\text { OR } \\
\text { 11. two or more prescriptions for hypertension drugs }\end{array}$ \\
\hline $\begin{array}{l}\text { Total respiratory } \\
\text { morbidity }\end{array}$ & $\begin{array}{l}5 \text { years prior to the } \\
\text { birth of the index child }\end{array}$ & $\begin{array}{l}\text { Physician } \\
\text { claims } \\
\text { Hospital } \\
\text { abstracts } \\
\text { Prescription } \\
\text { claims }\end{array}$ & $\begin{array}{l}\text { A woman was considered to have a history of total respiratory } \\
\text { morbidity if } 5 \text { years prior to the birth of the child she had: } \\
\text { One physician visit or hospitalisation in } 1 \text { year with: asthma, } \\
\text { acute bronchitis, chronic bronchitis, bronchitis not specified as } \\
\text { acute or chronic, emphysema or chronic airway obstruction } \\
\text { (ICD-9-CM codes } 466,490,491,492,493,496 \text {; ICD-10 codes } \\
\text { J20, J21, J40-J45). }\end{array}$ \\
\hline Diabetes & $\begin{array}{l}5 \text { years prior to the } \\
\text { birth of the index child }\end{array}$ & $\begin{array}{l}\text { Physician } \\
\text { claims } \\
\text { Hospital } \\
\text { abstracts } \\
\text { Prescription } \\
\text { claims }\end{array}$ & $\begin{array}{l}\text { A woman was considered to have a history of diabetes if } \\
5 \text { years prior to the birth of the child she had: } \\
\text { 1. At least two physician visits or one hospitalisation with a } \\
\text { diagnosis of diabetes (ICD-9-CM code 250; ICD-10-CA } \\
\text { codes E10-E14), OR } \\
\text { 2. One or more prescriptions for medications to treat diabetes }\end{array}$ \\
\hline $\begin{array}{l}\text { Ischaemic heart } \\
\text { disease }\end{array}$ & $\begin{array}{l}5 \text { years prior to the } \\
\text { birth of the index child }\end{array}$ & $\begin{array}{l}\text { Physician } \\
\text { claims } \\
\text { Hospital } \\
\text { abstracts } \\
\text { Prescription } \\
\text { claims }\end{array}$ & $\begin{array}{l}\text { A woman was considered to have a history of total respiratory } \\
\text { morbidity if } 5 \text { years prior to the birth of the child she had: } \\
\text { 1. At least two physician visits or one hospitalisation for IHD } \\
\text { (ICD-9-CM codes } 410-414 \text {, ICD-10 codes I20-I22, I24, } \\
\text { I25), OR } \\
\text { 2. At least one physician visit with a code listed above and } \\
\text { two or more prescriptions for IHD medications }\end{array}$ \\
\hline
\end{tabular}

studies using primary data collection. First, the use of linked clinical and administrative data is the study's greatest strength. It is difficult to ascertain and follow large groups of women whose children have a clinical diagnosis of FASD using primary data collection, due to challenges of attrition and length of follow-up time needed to obtain longer term outcomes of mothers (eg, suicide). In our study we identify mothers through children who are diagnosed at the Manitoba FASD Centre, which is one of the first and only provincially centralised FASD diagnostic clinics in Canada and as a result, one of the largest. Through the use of linked 
Table 5 Definitions of health services exposure/outcome variables

\begin{tabular}{|c|c|c|c|}
\hline Variable & Time frame & Database & Operation definition/ICD codes \\
\hline \multicolumn{4}{|l|}{ Physician visits } \\
\hline Ambulatory care visits & $\begin{array}{l}1 \text { year prior to birth } \\
\text { of index child }\end{array}$ & $\begin{array}{l}\text { Physician } \\
\text { claims }\end{array}$ & $\begin{array}{l}\text { Ambulatory visits are defined as all contacts with } \\
\text { physicians (family practitioner and specialists) that do not } \\
\text { include hospitalisations. These visits include office visits, } \\
\text { walk-in clinics, home visits, personal or home/nursing } \\
\text { home visits and outpatient department's visits. They do not } \\
\text { include emergency department visits. The type of visit is } \\
\text { determined by a tariff code in the physician claims data }\end{array}$ \\
\hline \multicolumn{4}{|r|}{ ( } \\
\hline Hospitalisations & $\begin{array}{l}3 \text { years before the } \\
\text { birth of the child }\end{array}$ & $\begin{array}{l}\text { Hospital } \\
\text { Abstracts }\end{array}$ & $\begin{array}{l}\text { A woman was considered to have a hospitalisation if a } \\
\text { billing claim was submitted to the provincial government for } \\
\text { services a hospital had provided in order to receive } \\
\text { reimbursement for care. These services include physician } \\
\text { visits, laboratory/pathology, X-ray/radiology, surgical } \\
\text { services, anaesthesia, postoperative care }\end{array}$ \\
\hline $\begin{array}{l}\text { Antenatal } \\
\text { hospitalisations }\end{array}$ & $\begin{array}{l}\text { During the } \\
\text { pregnancy of the } \\
\text { index child }\end{array}$ & $\begin{array}{l}\text { Hospital } \\
\text { Abstracts }\end{array}$ & $\begin{array}{l}\text { An antenatal hospitalisation is a hospitalisation in which a } \\
\text { woman was pregnant but did not deliver during the } \\
\text { hospitalisation of the index child. Reasons include } \\
\text { threatened preterm labour, haemorrhage, diabetes, } \\
\text { hypertensive disorders, abdominal pain etc. A woman was } \\
\text { considered to have an antenatal hospitalisation if there } \\
\text { was a record of hospitalisation not resulting in delivery in } \\
\text { the hospital abstracts database }\end{array}$ \\
\hline
\end{tabular}

Prenatal care visit

During the pregnancy of the index child

Late initiation of prenatal care

No care

Care initialised in first trimester

Care initialised in second trimester

Care initialised in third trimester

Low number of prenatal visits

Quality of prenatal care by the R-GINDEX
During the index child

During the pregnancy of the index child

During the pregnancy of the index child During the pregnancy of the index child During the pregnancy of the index child

During the pregnancy of the index child

During the pregnancy of the index child pregnancy of the
Physician claims

Physician claims

Physician claims

Physician claims

Physician claims

Physician claims

Physician claims

Physician claims Hospital Abstracts
A prenatal care visit was defined as the following physician tariff codes from the physician claims data: 8400 (complete prenatal assessment), 8401 (prenatal visits subsequent), 8501 (office visits, regional history and examination), 8507, 8509 (office visits), 8529 (regional intermediate visit or well baby care), 8540 (office visits complete history and physician examination, new patient), 8550 (consultation) A woman was considered as having late initiation of prenatal care if she began care after the first trimester of pregnancy (date of conception-91 days). This was determined by assessing when the first prenatal care tariff date was

A woman was considered as having no prenatal care if she had no visits with a prenatal care tariff during her pregnancy

A woman was considered as having care initialised in the first trimester if her first prenatal visit was between the date of conception to 91 days

A woman was considered as having care initialised in the second trimester if her first prenatal visit was between 92 to 189 days

A woman was considered as having care initialised in the third trimester if her first prenatal visit was between 189 days to the birth of the child

A woman was considered to have a low number of prenatal visits if she had less than five prenatal care visits as determined by counting the number of prenatal care tariffs she had during the pregnancy of the index child. The adequacy of prenatal care was determined using the R-GINDEX (Revised-Graduated Prenatal Care Utilisation Index). The following three variables were calculated using hospital and physician claims data: (1) gestational age of the newborn, (2) the trimester that prenatal care began; (3) the total number of prenatal visits during the pregnancy. 
Table 5 Continued

\begin{tabular}{|c|c|c|c|}
\hline Variable & Time frame & Database & Operation definition/ICD codes \\
\hline & & & $\begin{array}{l}\text { The G-INDEX classifies prenatal care into the following } \\
\text { categories: } \\
\text { 1. Inadequate prenatal care } \\
\text { 2. Intermediate prenatal care } \\
\text { 3. Adequate prenatal care } \\
\text { 4. Intensive prenatal care } \\
\text { 5. No care } \\
\text { 6. Missing information }\end{array}$ \\
\hline
\end{tabular}

Table 6 Definitions of social services exposure/outcome variables

\begin{tabular}{|c|c|c|c|}
\hline Variable & Time frame & Database & Operation definition/ICD codes \\
\hline \multicolumn{4}{|c|}{ Healthy baby program services } \\
\hline $\begin{array}{l}\text { Receipt of healthy baby } \\
\text { prenatal benefit }\end{array}$ & $\begin{array}{l}1 \text { year prior to } \\
\text { the birth of the } \\
\text { child }\end{array}$ & $\begin{array}{l}\text { Healthy Baby Community } \\
\text { Support Programme data } \\
\text { set }\end{array}$ & $\begin{array}{l}\text { The Healthy Baby Prenatal Benefit is income } \\
\text { supplement for pregnant women who live in } \\
\text { Manitoba and have a net family income of less } \\
\text { than } \$ 32,000 \text {. A woman was considered to have } \\
\text { received the prenatal benefit if at any time during } \\
\text { the eligibility period of the benefit ( } 14 \text { weeks, until } \\
\text { delivery) she received the benefit as coded in the } \\
\text { Healthy Baby Prenatal Benefit Data set }\end{array}$ \\
\hline $\begin{array}{l}\text { Participation in healthy } \\
\text { baby support programme }\end{array}$ & $\begin{array}{l}1 \text { year prior to } \\
\text { the birth of the } \\
\text { child }\end{array}$ & $\begin{array}{l}\text { Healthy Baby Community } \\
\text { Support Programme data } \\
\text { set }\end{array}$ & $\begin{array}{l}\text { The Healthy Baby Programme is a support } \\
\text { programme delivered by the province of Manitoba } \\
\text { to offer social support and learning opportunities } \\
\text { that encourage prenatal care and promote healthy } \\
\text { infant development. A woman was considered to } \\
\text { have participated in this programme if she had a } \\
\text { file in the Healthy Baby Community Support } \\
\text { Programme data set }\end{array}$ \\
\hline $\begin{array}{l}\text { InSight Mentoring } \\
\text { Program Participation }\end{array}$ & $\begin{array}{l}1 \text { year prior to } \\
\text { the birth of the } \\
\text { child }\end{array}$ & $\begin{array}{l}\text { Healthy Child Manitoba } \\
\text { Data }\end{array}$ & $\begin{array}{l}\text { The InSight programme is an outreach programme } \\
\text { where mentors provide intensive support to women } \\
\text { who are pregnant or have recently had a baby and } \\
\text { use substances. A woman was considered to have } \\
\text { participated in this programme if she had a file in } \\
\text { the Insight Program Database }\end{array}$ \\
\hline $\begin{array}{l}\text { Babies First/Families } \\
\text { First Screen }\end{array}$ & $\begin{array}{l}\text { After the birth } \\
\text { of the index } \\
\text { child }\end{array}$ & Healthy Child Manitoba & $\begin{array}{l}\text { Public health nurses in Manitoba attempt to assess } \\
\text { all families with newborns (using a validated } \\
\text { screen) within a week of discharge from the } \\
\text { hospitals. Families are asked about support and } \\
\text { challenges, including parents' alcohol and drug } \\
\text { use, mental health, education etc. Three or more } \\
\text { risk factors indicate that a family may require } \\
\text { additional supports such as intensive home } \\
\text { visiting, financial supports, support programs etc. } \\
\text { Before } 2003 \text {, this programme was known as the } \\
\text { Babies First home visiting programme }\end{array}$ \\
\hline $\begin{array}{l}\text { Record of a Families } \\
\text { First screen for the index } \\
\text { child }\end{array}$ & $\begin{array}{l}\text { After the birth } \\
\text { of the index } \\
\text { child }\end{array}$ & $\begin{array}{l}\text { Healthy Child Manitoba } \\
\text { Data }\end{array}$ & $\begin{array}{l}\text { A woman was identified as having a Families Frist } \\
\text { Screen if she had a record of a screen after the } \\
\text { birth of the index child in the Families First Data set }\end{array}$ \\
\hline Record of a Baby First & After the birth & Healthy Child Manitoba & A woman was identified as having a Babies Frist \\
\hline $\begin{array}{l}\text { Screen for the index } \\
\text { child }\end{array}$ & $\begin{array}{l}\text { of the index } \\
\text { child }\end{array}$ & Data & $\begin{array}{l}\text { Screen if she had a record of a screen after the } \\
\text { birth of the index child in the Families First Data set }\end{array}$ \\
\hline
\end{tabular}


Table 7 Definitions of demographic and socioeconomic exposure/outcome variables

\begin{tabular}{|c|c|c|c|}
\hline Variable & Time frame & Database & Operation definition/ICD codes \\
\hline $\begin{array}{l}\text { Mother's age at birth of } \\
\text { index child }\end{array}$ & $\begin{array}{l}\text { Year of birth of } \\
\text { index child }\end{array}$ & Registry & $\begin{array}{l}\text { A woman's age at birth of index child was } \\
\text { determined by subtracting the date of conception of } \\
\text { the index child by the birth date of the mother }\end{array}$ \\
\hline $\begin{array}{l}\text { History of a teen birth } \\
\text { or pregnancy }\end{array}$ & $\begin{array}{l}15 \text { years prior to } \\
\text { the birth of the } \\
\text { index child }\end{array}$ & Hospital Abstracts & $\begin{array}{l}\text { A woman was identified has having a history of teen } \\
\text { pregnancy or birth if they had the following } \\
\text { diagnostic codes from the ages 15-19: } \\
\text { Live birth: ICD-9-CM code V27, ICD-10-CA code } \\
\text { Z37 } \\
\text { Missed abortion: ICD-9-CM code } 632 \text {, } \\
\text { ICD-10-CA code O02.1 } \\
\text { Ectopic pregnancy: ICD-9-CM code } 633 \text {, } \\
\text { ICD-10-CA code O00 } \\
\text { Abortion: ICD-9-CM codes } 634-637 \text { ICD-10-CA } \\
\text { codes O03-O07 } \\
\text { Intrauterine death: ICD-9-CM code } 656.4 \text {, } \\
\text { ICD-10-CA code O36.4 } \\
\text { Or, a hospitalisation with one of the following } \\
\text { procedures: } \\
\text { Surgical termination of pregnancy: ICD-9-CM } \\
\text { codes } 69.01,69.51,74.91 \text {; CCI codes } 5 . C A .89 \text {, } \\
5 . C A .90 \\
\text { Surgical removal of extrauterine (ectopic) } \\
\text { pregnancy: ICD-9-CM codes } 66.62,74.3 ; \mathrm{CCI} \\
\text { code } 5 . C A .93 \\
\text { Pharmacological termination of pregnancy: } \\
\text { ICD-9-CM code } 75.0 ; \text { CCI code } 5 . C A .88 \\
\text { Interventions during labour and delivery, CCI } \\
\text { codes } 5 . M D .5,5 . M D .60\end{array}$ \\
\hline
\end{tabular}

Region of residenceurban/rural

Region of residenceRHA

Income Quintiles
Year of birth of index child

Year of birth of index child
Registry

Registry

Registry:

Census

Data 
Table 7 Continued

\begin{tabular}{lll}
\hline Variable & Time frame & Database \\
\hline & & \\
& & \\
& & \\
& & \\
Receipt of income & birth of the index & \\
assistance & Shild & Social Assistance \\
& & \\
& $\begin{array}{l}\text { Year of birth of } \\
\text { index child }\end{array}$ & Registry: \\
SES & Census Data
\end{tabular}

Maternal education level-high school completion

Involvement with the Justice System
During the entire study period

\section{Operation definition/ICD codes}

of the population. The income quintile measure is derived from the 2006 Statistics Canada Census data by aggregating household income to the dissemination area and then ranking neighbourhoods by income. Income quintiles are produced separately for urban and rural populations and are used as a proxy measure of individual SES. If the postal code is missing for a study participant, income quintiles cannot be calculated A woman was identified as having received income assistance if she was coded as having received income assistance from the social assistance management information database anytime during the period of 5 years before the birth of the child SES was defined according to income quintiles and income assistance data. A woman was considered to have:

- Low SES if she was categorised as being in income quintile 1 or had a receipt of income assistance

- Middle SES if she was categorised as being in income quintile 2 or 3

- High SES if she was categorised as being in income quintile 4 or 5

Education: enrolment, marks and assessment data
A woman was considered to have completed high school if she graduated within 6 years of starting grade nine. Criteria to assess if she graduated includes:

1. A Graduation Flag - a dichotomous variable derived from the 'Year End Status' variable on the student's high school marks data. If this variable indicated that the student graduated, then the student would be identified as a 4-year, 5 -year or 6-year high school graduatedepending on which year (4th, 5th or 6th) of being in high school did this 'Year End Status' first appear on the student's record.

If the yearend status variable is missing, two other measures are used to determine high school graduation/completion:

2. If the student earned $28-30$ or more high school credits

3. If the student earned 6 or more grade 12 credits regardless of how many credits in the total the student had earned

A woman was considered to have involvement with the justices system if she had a record of an incident in the Prosecutions Information Management System. Involvement type was classified by the following categories: (1) witness; (2) victim; (3) accused

RHA, Regional Health Authority; SES, socioeconomic status.

clinical and administrative data, the MCHP Repository allows the generation of a large population-based group of all women whose children were diagnosed with FASD in Manitoba since 1999 (preliminary n over 700 cases), which is the largest sample size in this field to date, enhancing the generalisability of our study results.

Second, the Manitoba FASD Centre offers a valid and reliable clinical diagnosis of FASD, and as a result we can be certain that women in this sample have given 
Table 8 Definitions of family history exposure/outcome variables

\begin{tabular}{|c|c|c|c|}
\hline Variable & Time frame & Database & Operation definition/ICD codes \\
\hline Marital status & $\begin{array}{l}\text { Time of birth of } \\
\text { index child }\end{array}$ & Registry & $\begin{array}{l}\text { A woman was considered to be married if her marital } \\
\text { status variable in the Registry was indicated as 'married' } \\
\text { or if she could be linked to a spouse through family } \\
\text { linkages developed at MCHP }\end{array}$ \\
\hline Gravidity & Entire study period & Hospital abstracts & $\begin{array}{l}\text { Gravidity is defined as the number of pregnancies, } \\
\text { regardless of the duration, including the present } \\
\text { pregnancy. Multiple fetuses (twins, triplets) count as one } \\
\text { pregnancy. Gravidity was calculated using the hospital } \\
\text { abstract data and was categorised as: } 0-3 \text { pregnancies, } \\
4-9,10-14\end{array}$ \\
\hline Parity & Entire study period & Hospital abstracts & $\begin{array}{l}\text { Parity is defined as the number of births a mother has } \\
\text { had after } 20 \text { weeks gestation. A multiple birth is counted } \\
\text { as one and stillbirths are included. Parity was calculated } \\
\text { using the hospital abstracts data and was categorised } \\
\text { as: } 0-3,4-9,10-14 \text {. }\end{array}$ \\
\hline $\begin{array}{l}\text { Birth order of the } \\
\text { child }\end{array}$ & $\begin{array}{l}\text { Time of birth of the } \\
\text { index child }\end{array}$ & Registry & $\begin{array}{l}\text { Birth order of the child was defined by the variable 'Birth } \\
\text { Order' in the Registry Centre data and was categorised } \\
\text { as: first, middle or last }\end{array}$ \\
\hline Any CFS & 5 years prior to the & Child and Family & A woman was defined as having any contact with CFS \\
\hline involvement & $\begin{array}{l}\text { birth of the index } \\
\text { child }\end{array}$ & $\begin{array}{l}\text { Services Information } \\
\text { System }\end{array}$ & $\begin{array}{l}5 \text { years prior to the birth of the index child if a record of } \\
\text { any contact with CFS existed in the Child and Family } \\
\text { Services Information System, this includes: (1) ever in } \\
\text { care-if a child was in care; (2) ever received CFS } \\
\text { services-if there were no children in care but the family } \\
\text { received protection or support services from CFS }\end{array}$ \\
\hline Children in care & $\begin{array}{l}5 \text { years prior to the } \\
\text { birth of the index } \\
\text { child }\end{array}$ & $\begin{array}{l}\text { Child and Family } \\
\text { Services Information } \\
\text { System }\end{array}$ & $\begin{array}{l}\text { A woman was defined as having children in care if she } \\
\text { had a child who had been removed from the home due } \\
\text { to a situation where authorities deemed their family } \\
\text { unable or unfit to look after them properly. In some } \\
\text { cases, children are voluntarily placed into care by their } \\
\text { parents, or they come into care for a variety of reasons, } \\
\text { including abuse and neglect, illness, death of a parent, } \\
\text { addiction issues or conflict in the family or disabilities }\end{array}$ \\
\hline Children receiving & 5 years prior to the & Child and Family & A woman was defined as having received protection or \\
\hline CFS & $\begin{array}{l}\text { birth of the index } \\
\text { child }\end{array}$ & $\begin{array}{l}\text { Services Information } \\
\text { System }\end{array}$ & $\begin{array}{l}\text { support services from CFS } 5 \text { years prior to the birth of } \\
\text { the index child. Will investigate both involvement of } \\
\text { children of the mother with CFS, as well as her own } \\
\text { involvement as a minor with CFS }\end{array}$ \\
\hline $\begin{array}{l}\text { FASD diagnosis } \\
\text { of index child }\end{array}$ & Entire study period & FASD Centre data & $\begin{array}{l}\text { The type of FASD diagnosis of the index child was } \\
\text { determined by the diagnosis variable in the FASD Centre } \\
\text { data and was categorised as the following: } \\
\text { (1) alcohol-ARND, (2) FAS or (3) pFAS }\end{array}$ \\
\hline $\begin{array}{l}\text { Other FASD } \\
\text { affected children }\end{array}$ & $\begin{array}{l}\text { At time of birth of } \\
\text { index child }\end{array}$ & FASD Centre & $\begin{array}{l}\text { A mother was identified as having other children affected } \\
\text { by FASD by a variable in the FASD Centre data set } \\
\text { 'other affected children' }\end{array}$ \\
\hline
\end{tabular}

ARND, alcohol-related neurodevelopmental disorder; CFS, Manitoba Child and Family services; FAS, fetal alcohol spectrum; FASD, fetal alcohol spectrum disorder; MCHP, Manitoba Centre for Healthy Policy and pFAS, partial FAS.

birth to children with FASD. Previous studies investigating characteristics of women who have consumed alcohol during pregnancy cannot confirm a clinically corroborated diagnosis of FASD in children. Therefore, these women may have different characteristics, use of healthcare and social services from those women whose children developed FASD.

Third, through the Repository, we have access to information on the whole population of Manitoba. These data facilitate the creation of clinically relevant comparison groups and accurate comparative analysis. Using the multiple available databases, comparison groups can be created using a host of matched characteristics, including age, sex, SES, geographic location and disease specific cohorts. ${ }^{42}$ These comparative analyses are difficult to perform using primary data recruitment methods as controls and cases can be difficult to identify, can take years to recruit and are subject to attrition. ${ }^{48}$ Moreover, 
through the use of hospital, physician, educational and social administrative data to develop exclusion criteria, the likelihood that women in the comparison group had children with undiagnosed FASD can be decreased. This is potentially a major limitation in previous studies as FASD is an extremely underdiagnosed condition.

Fourth, through leveraging the comprehensive, longitudinal databases available at MCHP, we can investigate novel health outcomes not yet studied. Specifically we can document the mental health diagnoses of women who give birth to children with FASD and determine rates of prenatal and postnatal anxiety and depression, as well as suicide attempts and completions. Women with alcohol substance use issues are at higher risk for prenatal and postpartum depression, ${ }^{52-54}$ investigating these outcomes specifically in mothers who give birth to children with FASD can provide evidence to policymakers responsible for optimising FASD prevention and support resources. Furthermore, maternal suicide is an increasing public health issue ${ }^{55}$ and investigating whether women who give birth to children with FASD are at increased risk for suicide is also important to optimise support resources and that these women do not slip through the cracks. Furthermore, due to the longitudinal nature of the data, an analysis of system usage of women before, during and after pregnancy can be conducted and compared to women in the general population whose children have not been diagnosed with FASD. This analysis is important to identify points for prevention, early intervention and treatment and effective resource allocation, as well as supporting the health and well-being of women who give birth to children with FASD. The Repository is ideal for these analyses, as the data accurately calculate the usage of healthcare services and have been validated for research purposes. ${ }^{42-44} 47485657$ MCHP data have been used to calculate the usage of the healthcare services among related populations in the past; for example, Brownell et $a \bar{p}^{8}$ used MCHP data to document the usage of health and social systems among children with FASD.

Finally, administrative data eliminate re-call bias and offer accurate information that can be isolated in critical periods of time throughout a study participant's lifespan. It is difficult to conduct studies on mothers with children with FASD due to stigmatisation and attrition of study participants. Furthermore, studies using primary data collection may be conducted after a significant time period has passed because of these women's pregnancies. This makes the recall of specific diagnoses, events and use of health services during the pregnancy difficult and increases the likelihood of inaccuracy. The use of our data is an important opportunity to ascertain accurate, unbiased information on these mothers and their use of health and social services and comorbid diagnoses before and during pregnancy and the postpartum period.

While the use of routinely collected population data has numerous advantages, there are a few limitations that warrant discussion. First, the use of a clinically referred FASD sample may limit the generalisability of findings, as we may be missing women and children who are not referred to this clinic. Owing to the complex nature of FASD, the multiple comorbidities associated with the disorder, underreporting, coding patterns of physicians and the complex multidisciplinary teams required to diagnose FASD, there is no algorithm that has been developed to identify children with FASD in the MCHP Repository using other data sources. Therefore, record linkage with the Manitoba FASD Centre is necessary to confirm a clinical diagnosis of FASD in children in Manitoba. However, the referrals to the clinic come from a wide variety of sources and from all regions in the province, strengthening the representativeness across populations. Second, while we have taken great care in excluding all mothers with possible prenatal alcohol exposure and children with a diagnosis of FASD, we cannot be certain that there are no women in our comparison group who do not have un-reported prenatal alcohol use or children with undiagnosed FASD. However, this would serve to weaken rather than strengthen any of our findings. Furthermore, as in all studies using administrative databases, this study is reliant on the accuracy of data submitted by the organisations that deliver services, and may have variations in data collection methods and compliance rates in the recording of information that may result in data errors. ${ }^{42}$ However, as previously stated, MCHP data have been extensively validated for conducting this type of research. Furthermore, outcome data are dependent on the individual making contact with the healthcare system and are, therefore, a report of treatment prevalence; thus, this study would exclude women with undiagnosed physical health or mental health disorders. Furthermore, the Repository does not capture information on interpersonal relationships, violence and abuse, psychological trauma or patient insight, which is important for the understanding of underlying causes of the drinking during pregnancy and would provide context to results of larger quantitative studies. However, data collection methods are often resource and time intensive and studies with patient insight often have small sample sizes, limiting generalisability. Although these types of data are not readily available in the Repository, the results of this study have the potential to lay the groundwork for the development of future work in this area. Finally, due to the exploratory nature of this study, there are multiple comparisons being performed and we acknowledge the potential for an inflated type 1 error, which is a limitation of this work. Future research should be conducted that corroborates the results from this proposed study.

\section{DISSEMINATION}

This study will be conducted at MCHP, which is a secure computing environment. Strict security measures are in place to protect the data files and to restrict access. The 
data in the Repository contain no identifiable personal information and are used only for research purposes. Data will be presented in a summary form, ensuring that identification of individuals is not possible.

To ensure the translation of the project's findings to policymakers, government stakeholders and community organisations, a study advisory group comprising physicians specialising in FASD, members of Healthy Child Manitoba (a provincial governmental organisation that works with the community to improve the well-being of Manitoba's children and youth) and FASD researchers has been established. During the final stages of the project, we will hold a forum to discuss policy implications arising from the project. Outputs from the project will include peerreviewed papers, summary reports in formats intended for policy and community organisations and presentations at academic conferences and government meetings.

\section{CONCLUSION AND POLICY IMPLICATIONS}

The databases brought together for this study and the results produced will generate a significant amount of longitudinal outcome data and contribute to our understanding of the life circumstances of mothers who give birth to children with FASD. The study results will provide an informed picture of the determinants of health that place women at increased risk of alcohol consumption during pregnancy, and giving birth to children with FASD. Moreover, the study results will offer insight into how women whose children have been diagnosed with FASD navigate health and social service systems during the perinatal and postnatal periods. These results will add to the evidence base and facilitate FASD prevention efforts through identifying: (1) high-risk women who should be targeted for prevention and intervention, (2) areas in health and social services that can be targeted for FASD prevention and support programmes to enhance service delivery to this population. Research providing insight into the factors that place women at risk for having children with FASD is vital for effective targeting and developing of policy resources that can help women cope with the influences and stresses in their lives in order to decrease prenatal alcohol consumption and ultimately prevent FASD.

\author{
Author affiliations \\ ${ }^{1}$ Department of Community Health Sciences, University of Manitoba, \\ Winnipeg, Manitoba, Canada \\ ${ }^{2}$ Manitoba Centre for Health Policy, University of Manitoba, Winnipeg, \\ Manitoba, Canada \\ ${ }^{3}$ Department of Paediatrics and Child Health, University of Manitoba, \\ Winnipeg, Manitoba, Canada \\ ${ }^{4}$ Department of Community Health Sciences, Manitoba Centre for Health \\ Policy, University of Manitoba, Winnipeg, Manitoba, Canada \\ ${ }^{5}$ Department of Paediatrics and Child Health, Section Head, Developmental \\ Paediatrics, University of Manitoba, Winnipeg, Manitoba, Canada \\ ${ }^{6}$ Manitoba Centre for Health Policy, University of Manitoba, Winnipeg, \\ Manitoba, Canada
}

Acknowledgements The authors acknowledge the Manitoba Centre for Health Policy for the use of data contained in the Population Health Research Data
Repository under project file HIPC\#2013/2014-2020 of the Government of Manitoba's Health Information Privacy Committee and under project HS16460 (H2013:221) of the University of Manitoba Faculty of Health Sciences, College of Medicine Health Research Ethics Board, as well as the following data providers: the Manitoba FASD Centre and the Winnipeg Regional Health Authority, Healthy Child Manitoba Office, the Manitoba FASD Centre and the Winnipeg Regional Health Authority, Manitoba Families, and the Department of Education and Training. The results and conclusions are those of the authors, and no official endorsement by the Manitoba Centre for Health Policy, Manitoba Health, Healthy Living and Seniors or other data providers is intended or should be inferred.

Contributors This study was conceived by DS. All authors contributed to the design of the study. DS will perform data analysis, and with MB, LLR, SL, AH-D and DC, will interpret the data. All authors participated in the preparation of this manuscript, revised it critically for important intellectual content and approved the version submitted for publication.

Funding Funding from this project was received from two Graduate Studentship Awards from Research Manitoba, the PhD Dissertation Award from Research Manitoba, the Evelyn Shapiro Award for Health Services Research from the Manitoba and from the Canadian Foundation on Fetal Alcohol Research.

Competing interests None declared.

Ethics approval This study was approved by the University of Manitoba's Health Research Ethics Board (HS16460(H2013:221)) and the Manitoba Health Information Privacy Committee (HIPC\#2013/2014-2020). Data access was approved by MCHP and the following data custodians: the Manitoba FASD Centre and the Winnipeg Regional Health Authority, Healthy Child Manitoba Office, the Manitoba FASD Centre and the Winnipeg Regional Health Authority, Manitoba Families, and the Department of Education and Training.

Provenance and peer review Not commissioned; externally peer reviewed.

Open Access This is an Open Access article distributed in accordance with the Creative Commons Attribution Non Commercial (CC BY-NC 4.0) license, which permits others to distribute, remix, adapt, build upon this work non-commercially, and license their derivative works on different terms, provided the original work is properly cited and the use is non-commercial. See: http://creativecommons.org/licenses/by-nc/4.0/

\section{REFERENCES}

1. Walker MJ, Al-Sahab B, Islam F, et al. The epidemiology of alcohol utilization during pregnancy: an analysis of the Canadian Maternity Experiences Survey (MES). BMC Pregnancy Childbirth 2011;11:52.

2. Chudley AE, Conry J, Cook JL, et al. Public Health Agency of Canada's National Advisory Committee on Fetal Alcohol Spectrum Disorder. Fetal alcohol spectrum disorder: Canadian guidelines for diagnosis. CMAJ 2005;172(Suppl):S1-S21.

3. Burd L, Cotsonas-Hassler TM, Martsolf JT, et al. Recognition and management of fetal alcohol syndrome. Neurotoxicol Teratol 2003;25:681-8.

4. May PA, Baete A, Russo J, et al. Prevalence and characteristics of fetal alcohol spectrum disorders. Pediatrics 2014;134:855-66.

5. Astley SJ. Profile of the first 1,400 patients receiving diagnostic evaluations for fetal alcohol spectrum disorder at the Washington State Fetal Alcohol Syndrome Diagnostic \& Prevention Network. Can J Clin Pharmacol 2010;17:e132-64.

6. Harris KR, Bucens IK. Prevalence of fetal alcohol syndrome in the Top End of the Northern Territory. J Paediatr Child Health 2003;39:528-33.

7. Kowlessar D. An examination of the effects of prenatal alcohol exposure on school-age children in Manitoba first nation community: a study of fetal alcohol syndrome prevalence and dysmorphology. University of Manitoba, 1997.

8. May PA, Fiorentino D, Coriale G, et al. Prevalence of children with severe fetal alcohol spectrum disorders in communities near Rome, Italy: new estimated rates are higher than previous estimates. Int $J$ Environ Res Public Health 2011;8:2331-51.

9. May PA, Fiorentino D, Phillip Gossage J, et al. Epidemiology of FASD in a province in Italy: Prevalence and characteristics of children in a random sample of schools. Alcohol Clin Exp Res 2006;30:1562-75 
10. May PA, Gossage JP, Kalberg WO, et al. Prevalence and epidemiologic characteristics of FASD from various research methods with an emphasis on recent in-school studies. Dev Disabil Res Rev 2009;15:176-92.

11. May PA, Gossage JP, Marais AS, et al. The epidemiology of fetal alcohol syndrome and partial FAS in a South African community. Drug Alcohol Depend 2007;88:259-71.

12. Petković G, Barisić I. FAS prevalence in a sample of urban schoolchildren in Croatia. Reprod Toxicol 2010;29:237-41.

13. Robinson GC, Conry JL, Conry RF. Clinical profile and prevalence of fetal alcohol syndrome in an isolated community in British Columbia. CMAJ 1987;137:203-7.

14. Williams RJ, Odaibo FS, McGee JM. Incidence of fetal alcohol syndrome in northeastern Manitoba. Can J Public Health 1999;90:192-4.

15. Armstrong EM, Abel EL. Fetal alcohol syndrome: the origins of a moral panic. Alcohol Alcohol 2000;35:276-82.

16. Abel EL, Hannigan JH. Maternal risk factors in fetal alcoho syndrome: provocative and permissive influences. Neurotoxicol Teratol 1995;17:445-62.

17. May PA, Gossage JP. Maternal risk factors for fetal alcohol spectrum disorders: not as simple as it might seem. Alcohol Res Health 2011:34:15-26.

18. World Health Organization. Global strategy to reduce the harmful use of alcohol. Geneva, Switzerland: WHO, 2010.

19. Esper LH, Furtado EF. Identifying maternal risk factors associated with fetal alcohol spectrum disorders: a systematic review. Eur Child Adolesc Psychiatry 2014;23:877-89.

20. Astley SJ, Bailey D, Talbot C, et al. Fetal alcohol syndrome (FAS) primary prevention through fas diagnosis: II. A comprehensive profile of 80 birth mothers of children with FAS. Alcohol Alcohol 2000;35:509-19.

21. Bagheri MM, Burd L, Martsolf JT, et al. Fetal alcohol syndrome: maternal and neonatal characteristics. J Perinat Med 1998;26:263-9.

22. Cannon MJ, Dominique Y, O'Leary LA, et al. Characteristics and behaviors of mothers who have a child with fetal alcohol syndrome. Neurotoxicol Teratol 2012;34:90-5.

23. Coyne KL, de Costa CM, Heazlewood RJ, et al. Pregnancy characteristics of women giving birth to children with fetal alcoho syndrome in Far North Queensland. Aust N Z J Obstet Gynaecol 2008;48:240-7.

24. Kvigne VL, Leonardson GR, Borzelleca J, et al. Characteristics of mothers who have children with fetal alcohol syndrome or some characteristics of fetal alcohol syndrome. J Am Board Fam Pract 2003;16:296-303

25. May PA, Gossage JP, Marais AS, et al. Maternal risk factors for fetal alcohol syndrome and partial fetal alcohol syndrome in South Africa: a third study. Alcohol Clin Exp Res 2008;32:738-53.

26. Miller LA, Shaikh T, Stanton C, et al. Surveillance for fetal alcohol syndrome in Colorado. Public Health Rep 1995;110:690-7.

27. Pierog S, Chandavasu O, Wexler I. The fetal alcohol syndrome: some maternal characteristics. Int J Gynaecol Obstet 1979;16:412-15.

28. Urban M, Chersich MF, Fourie LA, et al. Fetal alcohol syndrome among grade 1 schoolchildren in Northern Cape Province: prevalence and risk factors. S Afr Med J 2008;98:877-82.

29. Viljoen D, Croxford J, Gossage JP, et al. Characteristics of mothers of children with fetal alcohol syndrome in the Western Cape Province of South Africa: a case control study. J Stud Alcohol 2002;63:6-17.

30. Kvigne VL, Leonardson GR, Borzelleca J, et al. Alcohol use, injuries, and prenatal visits during three successive pregnancies among American Indian women on the Northern Plains who have children with fetal alcohol syndrome or incomplete fetal alcohol syndrome. Matern Child Health J 2008;12(Suppl 1):37-45.

31. Lewis PT, Shipman VC, May PA. Socioeconomic status, psychological distress, and other maternal risk factors for fetal alcohol spectrum disorders among American Indians of the Northern Plains. Am Indian Alsk Native Ment Health Res 2011;17:1-21.

32. May PA, Gossage JP, White-Country M, et al. Alcohol consumption and other maternal risk factors for fetal alcohol syndrome among three distinct samples of women before, during, and after pregnancy: the risk is relative. Am J Med Genet C Semin Med Genet 2004;127C:10-20.
33. Salmon J. Fetal alcohol spectrum disorder: New Zealand birth mothers' experiences. Can J Clin Pharmacol 2008;15:e191-213.

34. Jacobson SW, Jacobson JL, Sokol RJ, et al. Maternal recall of alcohol, cocaine, and marijuana use during pregnancy. Neurotoxicol Teratol 1991;13:535-40.

35. Adam A, Faouzi M, Yersin B, et al. Women and men admitted for alcohol intoxication at an emergency department: alcohol use disorders, substance use and health and social status 7 years later. Alcohol Alcohol 2016;51:567-75.

36. Burns L, Teesson M. Alcohol use disorders comorbid with anxiety, depression and drug use disorders. Findings from The Australian National Survey of Mental Health and Well Being. Drug Alcohol Depend 2002;68:299-307.

37. Hjorthøj C, Østergaard ML, Benros ME, et al. Association between alcohol and substance use disorders and all-cause and cause-specific mortality in schizophrenia, bipolar disorder, and unipolar depression: a nationwide, prospective, register-based study. Lancet Psychiatry 2015;2:801-8.

38. Siegfried N. A review of comorbidity: major mental illness and problematic substance use. Aust N Z J Psychiatry 1998;32:707-17.

39. Davis L, Uezato A, Newell JM, et al. Major depression and comorbid substance use disorders. Curr Opin Psychiatry 2008;21:14-18.

40. Ostacher MJ. Comorbid alcohol and substance abuse dependence in depression: impact on the outcome of antidepressant treatment. Psychiatr Clin North Am 2007;30:69-76.

41. Astley SJ, Bailey D, Talbot C, et al. Fetal alcohol syndrome (FAS) primary prevention through FAS diagnosis: I. Identification of high-risk birth mothers through the diagnosis of their children. Alcohol Alcohol 2000;35:499-508.

42. Jutte DP, Roos LL, Brownell MD. Administrative record linkage as a tool for public health research. Annu Rev Public Health 2011;32:91-108.

43. Roos LL, Menec V, Currie RJ. Policy analysis in an information-rich environment. Soc Sci Med 2004:58:2231-41.

44. Roos LL, Nicol JP. A research registry: uses, development, and accuracy. J Clin Epidemiol 1999;52:39-47.

45. Cormier RA, Dell CA, Poole N. Women and substance abuse problems. BMC Womens Health 2004;4(Suppl 1):S8.

46. Drabble LA, Poole N, Magri R, et al. Conceiving risk, divergent responses: perspectives on the construction of risk of FASD in six countries. Subst Use Misuse 2011;46:943-58

47. Roos LL, Gupta S, Soodeen RA, et al. Data quality in an information-rich environment: Canada as an example. Can J Aging 2005;24(Suppl 1):153-70.

48. Roos LL Jr, Nicol JP, Cageorge SM. Using administrative data for longitudinal research: comparisons with primary data collection. J Chronic Dis 1987;40:41-9.

49. Cook JL, Green CR, Lilley CM, et al. Fetal alcohol spectrum disorder: a guideline for diagnosis across the lifespan. CMAJ 2016;188:191-7.

50. Burger PH, Goecke TW, Fasching PA, et al. [How does maternal alcohol consumption during pregnancy affect the development of attention deficit/hyperactivity syndrome in the child]. Fortschr Neurol Psychiatr 2011:79:500-6.

51. Infante MA, Moore EM, Nguyen TT, et al. Objective assessment of ADHD core symptoms in children with heavy prenatal alcohol exposure. Physiol Behav 2015;148:45-50.

52. Homish GG, Cornelius JR, Richardson GA, et al. Antenatal risk factors associated with postpartum comorbid alcohol use and depressive symptomatology. Alcohol Clin Exp Res 2004;28:1242-8.

53. Katon W, Russo J, Gavin A. Predictors of postpartum depression. $J$ Womens Health (Larchmt) 2014;23:753-9.

54. Tebeka S, Le Strat Y, Dubertret C. Developmental trajectories of pregnant and postpartum depression in an epidemiologic survey. $J$ Affect Disord 2016;203:62-8.

55. Patrick K. It's time to put maternal suicide under the microscope. CMAJ 2013;185:1115.

56. Brownell MD, Roos NP, Roos LL. Monitoring health reform: a report card approach. Soc Sci Med 2001;52:657-70.

57. Kozyrskyj AL, Mustard CA. Validation of an electronic population-based prescription database. Ann Pharmacother 1998;32:1152-7.

58. Brownell MD, de B Hanlon Dearman AC, Macwilliam LR, et al. Use of health, education, and social services by individuals with fetal alcohol spectrum disorder. J Popul Ther Clin Pharmacol 2013;20: e95-e106. 